\title{
Survival, Germination, and Growth of Epichloë typhina and Significance of Leaf Wounds and Insects in Infection of Orchardgrass
}

Stephen C. Alderman, United States Department of Agriculture-Agricultural Research Service, National Forage Seed Production Research Center, Corvallis, OR 97331

\begin{abstract}
Alderman, S. C. 2013. Survival, germination, and growth of Epichlö̈ typhina and significance of leaf wounds and insects in infection of orchardgrass. Plant Dis. 97:323-328.

Epichlö typhina is an important stroma-producing endophytic ascomycete that is responsible for significant yield loss in orchardgrass (Dactylis glomerata) seed production fields. Infection is presumed to occur through leaves or stems, although details of the infection process and conditions that favor leaf infection are not well understood. The primary objectives of this study were to investigate the early stages of infection, including the effect of temperature or water potential on ascospore germination and subsequent growth of E. typhina, the tolerance of ascospores to desiccation, the requirement of leaf wounds for infection of orchardgrass by E. typhina, and the potential for insects to facilitate infection. Ascospores tolerated dry conditions, with at least

E. typhina was greatest at $25^{\circ} \mathrm{C}$, with little to no growth at 5 and $35^{\circ} \mathrm{C}$. Mycelial growth decreased with decreasing water potential from -0.3 to $-10 \mathrm{MPa}$. Ascospore germination on leaves was predominantly hyphal at wound sites and iterative (conidiogenous) at sites without wounds. E. typhina typically entered leaves through wounds. Direct penetration was rarely observed and appeared to be associated with ascospore clusters. Germ tubes were significantly longer at sites with honeydew deposits from the bird cherry-oat aphid than at sites without honeydew. Growth of E. typhina was also observed at feeding sites of eriophyid mites, suggesting that leaf-wounding or sap-excreting insects support epiphyllous growth of E. typhina on leaves.
\end{abstract} $40 \%$ surviving 12 days under desiccation. Germination and growth of
Epichlö typhina (Pers.) Tul. \& C. Tul. is a heterothallic, stromaproducing, endophytic ascomycete $(8,31)$ with a wide host range, including 41 genera of temperate grasses (10). In the early stages of host inflorescence development, E. typhina proliferates on the surface of the developing inflorescence, encasing it in a felt-like stoma $(14,25)$. Stromata are initially white but turn ochre-yellow to yellow-orange as they mature following fertilization. The disease is commonly referred to as choke. Each stroma produces conidia of one of two mating types. Flies (Botanophila spp. [previously Phorbia spp.]) which feed, defecate conidia, and lay eggs on stromata of E. typhina. $(6,7)$ are largely responsible for transfer of conidia and subsequent fertilization, although other agents such as slugs may also facilitate fertilization (21). In addition, E. typhina ascospores have fertilized stromata under experimental conditions and likely play a role in the widespread fertilization of laterdeveloping stromata under field conditions (2).

E. typhina typically infects host ovaries during flowering, which results in infected seed and subsequent infected plants $(8,25)$. However, in Dactylis glomerata L. (orchardgrass), establishment of E. typhina in ovaries is not known to occur $(8,9,17,24)$, and attempts to obtain seed infections in orchardgrass and subsequent infected plants have not been successful $(17,27)$.

In the Willamette valley of Oregon, where more than $90 \%$ of the U.S. orchardgrass seed is produced, E. typhina was first reported in orchardgrass seed production fields in 1997 (1). In surveys in

Corresponding author: S. Alderman, E-mail: aldermas@onid.orst.edu

Mention of trade names or commercial products in this publication is solely for the purpose of providing specific information and does not imply recommendation or endorsement by the United States Department of Agriculture (USDA). USDA is an equal opportunity provider and employer.

Accepted for publication 30 August 2012.

http://dx.doi.org/10.1094/PDIS-01-12-0075-RE

This article is in the public domain and not copyrightable. It may be freely reprinted with customary crediting of the source. The American Phytopathological Society, 2013.
1998, choke was found in $70 \%$ of orchardgrass fields in the Willamette valley, with incidence in some fields exceeding $20 \%$ (19). By the third or fourth year of production, incidence of choke can exceed $30 \%(15,16)$. Symptomatic plants appear in the second year of production, and incidence and severity increase with each consecutive year $(15,16)$. However, low levels of choke were occasionally recorded from first-year fields during choke surveys in England and Wales $(15,16)$. In spring-planted orchardgrass fields in Oregon, reproductive tillers are not produced until the following year, because vernalization is required for floral induction in orchardgrass (11). E. typhina infects orchardgrass systemically, and a low density of hyphae can be found in leaves and stems. Schardl and Phillips (26) reported an absence or low level of alkaloids in $E$. typhina from various $\mathrm{C} 3$ grasses, unlike the high levels of alkaloids produced by the asexual hybrid anamorph of E. typhina, Neotyphodium coenophialum, which are toxic to grazing animals. Consequently, there is apparently no impact of E. typhina infection on forage quality and, other than stromata development, infected plants are asymptomatic. Currently, the only management option for E. typhina in orchardgrass is a shorter rotation $(20,23)$. Prior to the appearance of choke disease, orchardgrass fields were typically in production one to several decades.

The means by which E. typhina initiates infection in orchardgrass is not well understood. Western and Cavett (30) proposed that E. typhina infects orchardgrass at harvest by growing down the cut stalks but they also found that high humidity was required, and that desiccated host tissues were unsuitable for infection. In western Oregon, conditions during harvest are nearly always warm and dry, and stalks desiccate soon after cutting. Leyronas and Raynal (17), in artificial inoculation experiments, obtained infected plants when ascospores of E. typhina were applied to ends of vegetative tillers cut to a height of $1 \mathrm{~cm}$; however, no established infections resulted from inoculation of cut stalks.

Understanding the details of how E. typhina infects orchardgrass, and the environmental conditions under which this occurs, could be particularly helpful in developing strategies for choke management. The primary objectives of this study were to investigate the early stages of infection, including the effect of temperature or water potential on ascospore germination and subsequent 
growth of E. typhina, the tolerance of ascospores to desiccation, the requirement of leaf wounds for infection of orchardgrass by $E$. typhina, and the potential for insects to facilitate infection.

\section{Materials and Methods}

Plants and inoculum source. About 40 naturally infected plants were collected from a commercial orchardgrass seed production field near Corvallis, OR. One or two tillers from each plant were transplanted and grown in plastic cone-tainers (approximately $7 \mathrm{~cm}$ in diameter by $26 \mathrm{~cm}$ long; Steuwe \& Sons) containing SB40 Sunshine Growing Mix (Sun Gro Horticulture) and maintained at in a greenhouse at 20 to $30^{\circ} \mathrm{C}$ with supplemental lighting to provide 16 $\mathrm{h}$ of light per day. Infected plants were fertilized weekly with Technigro 20-18-20 all-purpose fertilizer (Sun Gro Horticulture) and maintained through clonal propagation. Orchardgrass plants used in all infection studies were 5 to 8 weeks old and grown from seed in a greenhouse free of E. typhina-infected plants but with the same temperature and light setting as for infected plants.

To induce stromata, plants were vernalized at $8^{\circ} \mathrm{C}$ and $8 \mathrm{~h}$ of light. After 16 weeks, plants were placed in a growth chamber at $15^{\circ} \mathrm{C}$ and $16 \mathrm{~h}$ of light for 2 weeks prior to transfer to the greenhouse. Stromata generally appeared within several weeks of transfer to the greenhouse. For ascospore production, stromata were fertilized by collecting conidia from the surface of 10 to 20 stromata with an artist's paint brush, alternately brushing the stromata and dipping the brush in a flask containing $10 \mathrm{ml}$ of deionized water, then using the brush to apply the conidial suspension to the stromata. Mature stromata were recognized by their ochre-yellow to yellow-orange color and swelling of perithecia beyond the stroma surface.

For in vitro studies, three single-ascospore isolates (ET-1, ET-3, and ET-4) were obtained by taping stromata, freshly collected from an orchardgrass seed production field near Corvallis, OR, to the inside of a petri dish lid over water agar (one stroma per dish). Individual ascospores deposited on water agar beneath the stromata were transferred to corn meal malt extract agar (CMMA). A singleascospore culture was obtained from each of three stromata.

Survival, germination, and growth of E. typhina. The survival capability of ascospores of E. typhina, in terms of tolerance to desiccation, was evaluated by placing each of five stromata on an aluminum screen $\left(1-\mathrm{mm}^{2}\right.$ openings) over 200.5 -by-1.0-cm segments cut from uncoated polyester tape (Burkard Mfg, Ltd.). The segments were positioned on a glass slide directly under the stroma in each of five petri dishes lined with saturated tissue paper. At about 10-min intervals, the slides were examined under a dissecting microscope until ascospores were observed on the tape segments. A tape segment with ascospores from each stroma was placed on each of five strips ( 2 by $5 \mathrm{~cm}$ ) of the aluminum screen in a desiccator containing calcium sulfate (Dreirite) at room temperature $\left(23 \pm 3^{\circ} \mathrm{C}\right)$. After $0,3,5,8,12$, and 16 days, a screen with five replicate tape pieces was moved to a petri dish lined with saturated tissue paper to encourage germination. After $48 \mathrm{~h}$, the plastic segments were placed on a glass slide, covered with aniline blue stain (30 $\mathrm{mg}$ of aniline blue, $20 \mathrm{ml}$ of deionized water, $10 \mathrm{ml}$ of glycerol, $10 \mathrm{ml}$ of lactic acid, and 1 drop of Tween 20) and examined at $\times 200$. Ascospore germination (recognized by presence of conidiophores or germ tubes) was recorded for the first 50 ascospores encountered on each replicate tape segment. The experiment was conducted twice.

Germination of ascospores of E. typhina with respect to temperature was evaluated by slicing four stromata into $0.5-\mathrm{cm}$ pieces and placing segments from each stromata in a separate test tube containing $10 \mathrm{ml}$ of deionized water + surfactant (two drops Tween 20 per $100 \mathrm{ml}$ of water). Each tube was vortexed for $10 \mathrm{~s}$ and four replicate 5- $\mu$ l drops from each tube were placed on each of 28 cover glasses (number 1, 22 by $22 \mathrm{~mm}$ ). Four cover glass were placed in each of seven petri dishes lined with saturated tissue and a dish was placed in an incubator without light at 5, 10, 15, 20, 25, 30 , or $35^{\circ} \mathrm{C}$. After $4,8,12$, or $24 \mathrm{~h}$, a cover glass was removed from each dish and inverted onto a drop of aniline blue stain.
Germination was assessed in each of the four replicate drops per slide. Percentage germination was based on the first 50 spores encountered in each drop. The experiment was conducted twice. Results from each run were similar; therefore, means and standard errors were calculated based on pooled data from each of the two runs.

To determine the effect of temperature on growth rate of $E$. typhina, a 2-mm-diameter agar plug from a 3- to 5-week-old culture was transferred to the center of each of 35 CMMA plates, and 5 replicate plates were placed in a growth chamber without light at $5,10,15,20,25,30$, or $35^{\circ} \mathrm{C}$. Radial growth was measured at 3 - to 6-day intervals for 3 weeks. The experiment was conducted twice for one isolate and repeated with each of two other single-ascospore isolates. Mean and standard errors were based on pooled data, because results for each experimental run were similar, based on analysis of variance.

To determine the effect of water potential on growth of $E$. typhina, CMMA was amended with KCL to $-0.3,-2,-4,-6,-8$, or $-10 \mathrm{MPa}$. Water potentials of the agar were verified using a Wescor HT33 dewpoint hygrometer and C-52 chambers, calibrated against $\mathrm{KCL}$ solutions of known water potential at $20^{\circ} \mathrm{C}$. A $2-\mathrm{mm}$ plug from a 3- to 4-week-old culture was transferred to the center of each of five replicate plates per treatment combination, and plates were placed in an incubator at $20^{\circ} \mathrm{C}$ without light. The experiment was run twice for each of two single-ascospore isolates. Mean and standard errors were based on pooled data.

Germination and infection studies on leaves. Germination of E. typhina ascospores was evaluated on leaves subject to compression (crushing) wounds or at the cut ends of leaves. To evaluate germination of ascospores at compression leaf wound sites, five replicate plants (grown in cone-containers) were each placed in a clear plastic bag containing paper towels saturated with water and positioned horizontally on a laboratory bench. At two to four sites on each of four to six leaves, a wound was created at about midleaf length by crimping the leaves with a hemostat. Aluminum screening was placed approximately $1 \mathrm{~cm}$ over the injured leaves and a stroma placed on the screen. Paper towels saturated with water were positioned near the screens to provide high humidity and the bags were closed. After about 20 to $30 \mathrm{~min}$, a leaf was removed to verify that ascospores were released, and then the stromata were removed. At $48 \mathrm{~h}$ after ascospore deposition, an injured, inoculated leaf was removed from each plant, cut into 5-mm-length segments, placed on a glass slide, covered with aniline blue stain, and examined at $\times 100$ or $\times 200$. A similar set of control samples was collected from uninjured leaves. Percent germination was based on the first 50 spores encountered on each leaf segment. The experiment was conducted three times.

In a separate experiment, uninjured leaves on three plants were sprayed with ascospores $\left(1 \times 10^{4}\right.$ ascospores $\left./ \mathrm{ml}\right)$ using an artist's air brush, then placed in large clear plastic bags with moist tissues to maintain high humidity. After $72 \mathrm{~h}$ of incubation at room temperature, three 1-cm-long leaf segments from each plant were excised. The midrib was cut out and the segments were covered with aniline blue stain ( $30 \mathrm{mg}$ of aniline blue, $20 \mathrm{ml}$ of water, 10 $\mathrm{ml}$ of glycerol, $10 \mathrm{ml}$ of lactic acid, and 1 drop of Tween 20) and examined at $\times 200$ and $\times 400$ for evidence of direct penetration from germinating ascospores. The experiment was conducted twice. In addition, three leaf segments from each of three naturally infected plants maintained in the greenhouse were excised, covered with aniline blue stain, and examined for evidence of internal to external growth of E. typhina on leaves.

To investigate germination of ascospores of E. typhina at cut leaf surfaces and subsequent growth into leaves, five plants were cut to $5 \mathrm{~cm}$ in height. Then, $1-\mu \mathrm{l}$ drops, each containing 30 to 50 ascospores, were placed on the cut ends of three to five leaves on each plant. Control leaves received drops of deionized water. Ascospores were obtained by placing stromata on wire mesh screens over 22- $\mathrm{mm}^{2}$ cover glasses in petri dishes containing saturated tissues. Ascospore deposited on the sides were collected in a drop of water and ascospore concentration adjusted to 30 to 50 asco- 
spores $/ \mu \mathrm{l}$. A clear plastic tube $(2.5 \mathrm{~cm}$ inside diameter by $30 \mathrm{~cm}$ long) was secured to a ring stand and positioned over the cut leaves of each plant. Air from an aquarium pump was bubbled through two 500-ml flasks of deionized water and connected via clear plastic tubing to a stopper at the top of each tube to maintain high humidity conditions. After 10 days, $1-\mathrm{cm}$ lengths of the inoculated leaf ends were excised and placed in 95\% ETOH and stored on a laboratory bench. After a minimum of 7 days in ETOH, the tissues were placed in $3 \%$ hydrogen peroxide, rinsed for $1 \mathrm{~min}$, stained in aqueous aniline blue $(0.6 \mathrm{mg} / \mathrm{ml})$ for $1 \mathrm{~h}$, acidified in $30 \%$ lactic acid for $20 \mathrm{~min}$, mounted in glycerol on a glass slide, covered with a cover glass, and examined at $\times 200$ and $\times 400$ magnification. The experiment was conducted twice.

Wounds from eriophyid mites. To determine whether leaf surface wounds from eriophyid mites would stimulate growth of $E$. typhina on leaves, five plants infested with eriophyid mites (naturally infested in the greenhouse but source of mites unknown) from a greenhouse free of choke were placed in a plastic-covered wood frame chamber with a vaporizer to provide high humidity. Three freshly cut stromata, with the stem placed in test tubes containing water, were secured to bamboo stakes above the plants. Cover glasses $\left(22 \mathrm{~mm}^{2}\right)$ were placed near the base of plants to verify ascospore release and deposition. Plants were placed in a dew chamber (Percival Mfg. Co.) at $20^{\circ} \mathrm{C}$ with $12 \mathrm{~h}$ of dew duration per day and a 12-h light period without dew per day for 7 days. Leaf samples were cut into 1-cm-long segments, placed on a glass slide,

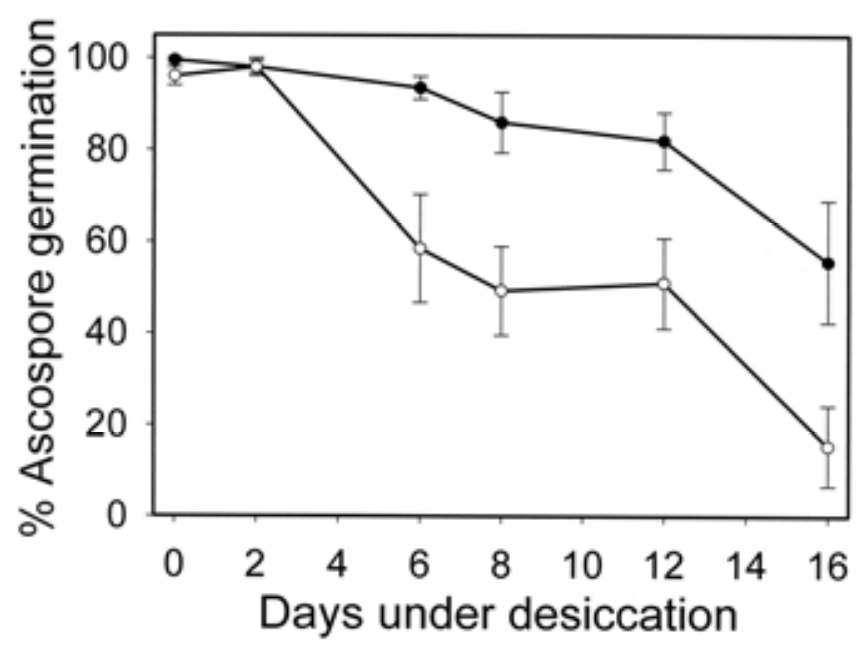

Fig. 1. Percent germination of ascospores of Epichloë typhina following 0 to 16 days of exposure to desiccation in each of two experimental runs.

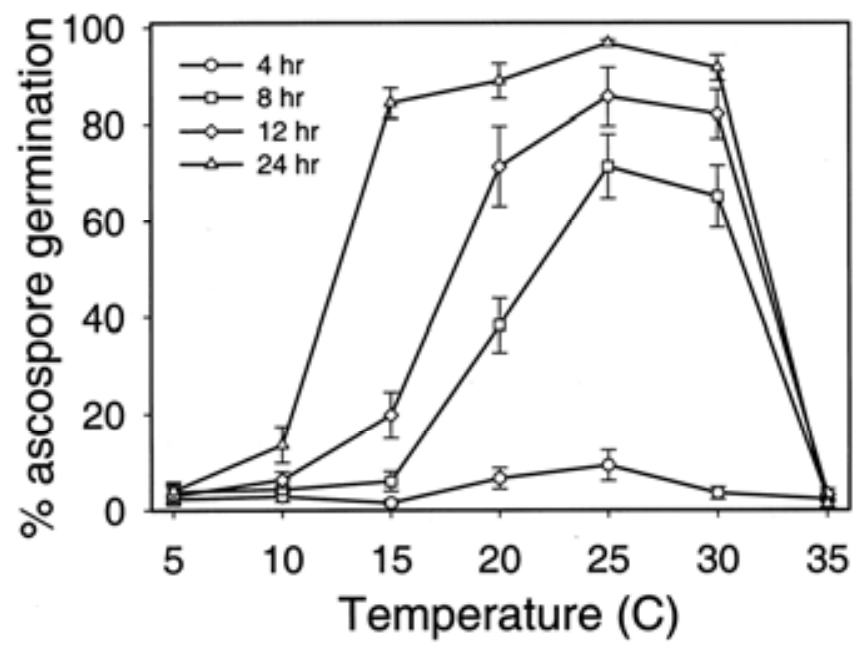

Fig. 2. Germination of ascospores of Epichloë typhina on glass slides after 4, 8, 12, or $24 \mathrm{~h}$ at 5 to $35^{\circ} \mathrm{C}$. Data pooled from two experimental runs. covered with aniline blue stain $(30 \mathrm{mg}$ of aniline blue, $20 \mathrm{ml}$ of water, $10 \mathrm{ml}$ of glycerol, $10 \mathrm{ml}$ of lactic acid, and 1 drop of Tween 20 ), covered with a cover glass, and examined at $\times 200$ and $\times 400$.

Effect of aphid honeydew on ascospore germination. To evaluate the effect of aphid honeydew on ascospore germination, the bird cherry-oat aphid (Rhopalosiphum padi L.) was selected because of its prevalence on orchardgrass on greenhouse plants and in commercial orchardgrass fields. Aphids were transferred to 3week-old orchardgrass plants by placing leaves with aphids among the leaves of the plants. Plants were maintained in wooden-framed cages covered with thrips exclusion screening. The cages where placed on a laboratory bench under a greenhouse high-pressure sodium light to provide $16 \mathrm{~h}$ of light per day.

Ascospores were obtained by placing stromata on wire mesh screens over $22-\mathrm{mm}^{2}$ cover glasses in petri dishes containing tissues saturated with water. Ascospores deposited on the sides were collected in a drop of water and ascospore concentration adjusted to 10 to 20 ascospores/ $\mu$ l. Then, $3-\mu l$ drops containing approximately 30 to 60 ascospores were deposited on a leaf from each of five plants. Each drop was placed on a drop of honeydew. Drops were placed on a similar set of control leaves which did not have honeydew. The leaves were excised and placed in a petri dish with saturated paper towels to maintain high humidity. After $24 \mathrm{~h}$, the inoculation sites were cut from the leaves, placed on a glass slides, covered with aniline blue stain, covered with a cover glass, and examined at $\times 200$ magnification. The longest germ tube length for each of the first 20 ascospores encountered at each inoculation site was measured using a calibrated ocular micrometer. A $t$ test was used to determine whether mean germ tube length per leaf differed significantly between the honeydew and control groups. The experiment was conducted twice.

\section{Results}

The percent germination of E. typhina ascospores decreased with increasing duration of desiccation from 2 to 16 days (Fig. 1). Although the percentage of survival differed between the two experimental runs, at least $40 \%$ of the ascospores remained viable after 12 days of desiccation. Ascospores germinated between 5 and $35^{\circ} \mathrm{C}$ (Fig. 2), with germ tubes present within $4 \mathrm{~h}$ at $25^{\circ} \mathrm{C}$. However, at $24 \mathrm{~h}$, fewer than $5 \%$ of ascospores germinated at 5 and $35^{\circ} \mathrm{C}$, and fewer than $15 \%$ germinated at $10^{\circ} \mathrm{C}$. Growth rate of $E$. typhina on CMMA increased from 5 to $25^{\circ} \mathrm{C}$, then declined (Fig. 3). A maximum growth rate of $1.6 \mathrm{~mm} /$ day occurred at $25^{\circ} \mathrm{C}$. Growth of E. typhina declined with decreasing water potential of CMMA from -0.3 through $-10 \mathrm{MPa}$ (Fig. 4). Little to no growth occurred at $-8 \mathrm{MPa}$.

In ascospore germination studies on leaves with or without compression wounds, three types of germination were observed: itera-

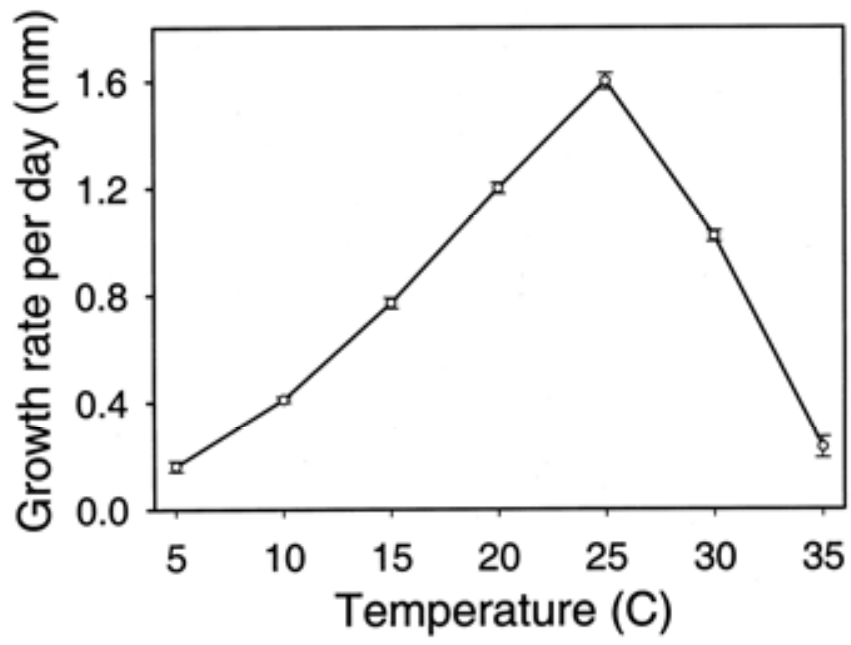

Fig. 3. Radial growth rate per day of Epichloë typhina during 3 weeks on corn meal malt extract agar at 5 to $35^{\circ} \mathrm{C}$. Data pooled from two experimental runs. 
tive (conidia produced), hyphal, or both iterative and hyphal (Fig. 5). Significantly more iterative germination of ascospores occurred at noninjured than at injured sites on leaves (Table 1).

In plants showered with ascospores and placed at high humidity for $72 \mathrm{~h}$, ascospore germination was typically iterative. However, in each of two experimental runs, hyphal tips from a few germinating ascospores, associated with clusters of about three to six ascospores, penetrated the leaf epidermis (Fig. 6A). The extent of growth into leaves was not determined. However, in naturally infected plants, growth of E. typhina from the interior to exterior of leaves was observed on most leaves examined (Fig. 6B). External hyphal growth was common on leaves of systemically infected plants and was observed on all leaves examined.

At the cut ends of leaves, ascospores germinated, hyphae grew into the cut ends, and conidia were observed at the cut ends (Fig. $6 C)$. By 10 days after inoculation, the mean \pm standard error hyphal growth into the leaf was $300 \pm 27.63 \mu \mathrm{m}$ ( $n=15$ leaves) in experimental run one and $321.75 \pm 53.15 \mu \mathrm{m}(n=9$ leaves $)$ in experimental run two. Germ tube lengths on leaf surfaces were significantly longer in the presence of aphid honeydew than in water controls (Table 2). At 10 eriophyid mite feeding sites, ascospores germinated and mycelial growth was observed (Fig. 6D).

\section{Discussion}

The mode of infection of orchardgrass by E. typhina has not yet been characterized and there are currently no consistent or reliable nonsterile experimental systems for infecting orchardgrass and inducing symptomatic (choked) plants. Systemic or endophytic infection of orchardgrass results from the internal colonization of tiller primordia within the plant crown (14). How exactly these primordia are initially infected remains a mystery. Leaf infections from cut ends of leaves, as demonstrated in this study, are not likely an avenue for infection given the relatively slow rate of growth of E. typhina, the rapid elongation of young leaves, and senescence of older leaves. At temperatures of 20 to $25^{\circ} \mathrm{C}$, growth of E. typhina in media was $1.6 \mathrm{~mm} /$ day but observations of $E$. typhina at cut ends of leaves at 10 days revealed little progress internally into the cut ends of leaves. Considering the developmental dynamics of orchardgrass tillers, in which leaves progress from a state of elongation, maturity, and senescence, more likely avenues for infection within the plant crown are surface growth of $E$. typhina, which is a more efficient means of reaching and establishing infections in the basal portion of the tillers, or spores that either land on or are washed from rain to the base or crown of the plants.

Epiphyllous mycelial growth of Neotyphodium and Epichlö̈ spp. has been described on other grass hosts (18). In the case of $E$.

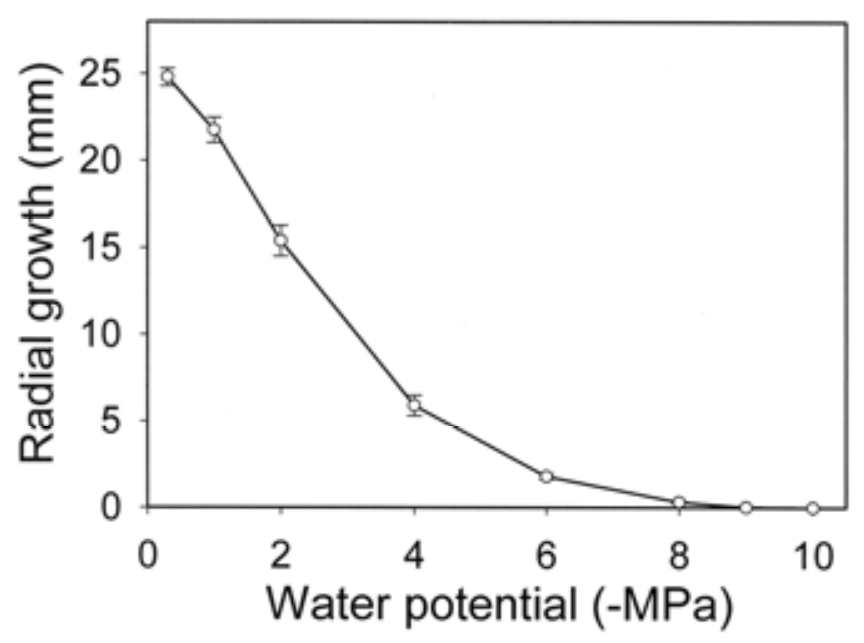

Fig. 4. Radial growth of Epichloë typhina after 20 days without light on corn meal malt extract agar adjusted with $\mathrm{KCL}$ to -3 to $-100 \mathrm{MPa}$. Data pooled from two experimental runs. typhina in orchardgrass, the stimulation of hyphal germination of ascospores and subsequent growth in the presence of nutrients from plant sap or aphid secretions may provide a means to support epiphyllous growth of E. typhina on leaf surfaces. Ascospores that land near the base of plants or are washed from rain into the crown would best be positioned for epiphyllous growth and subsequent infection. In addition, conidia from germinating ascospores may also be washed to the base of the plant during rains. Infection of Poa ampla leaves by Neotyphodium conidia as well as spread of conidia by water has been documented $(27,28)$.

Little growth of E. typhina occurred at $5^{\circ} \mathrm{C}$, which suggests that limited development of the fungus would occur within hosts during the cold temperatures of winter. Ju (12) found a low endophyte level in tall fescue during the winter in Georgia, and little growth of the endophyte $N$. coenophialum at $10^{\circ} \mathrm{C}$. The critical time for $E$. typhina to migrate to and become established in tiller primordia would likely be during the fall, when conditions are still warm enough for fungal growth and new vegetative tillers are developing.
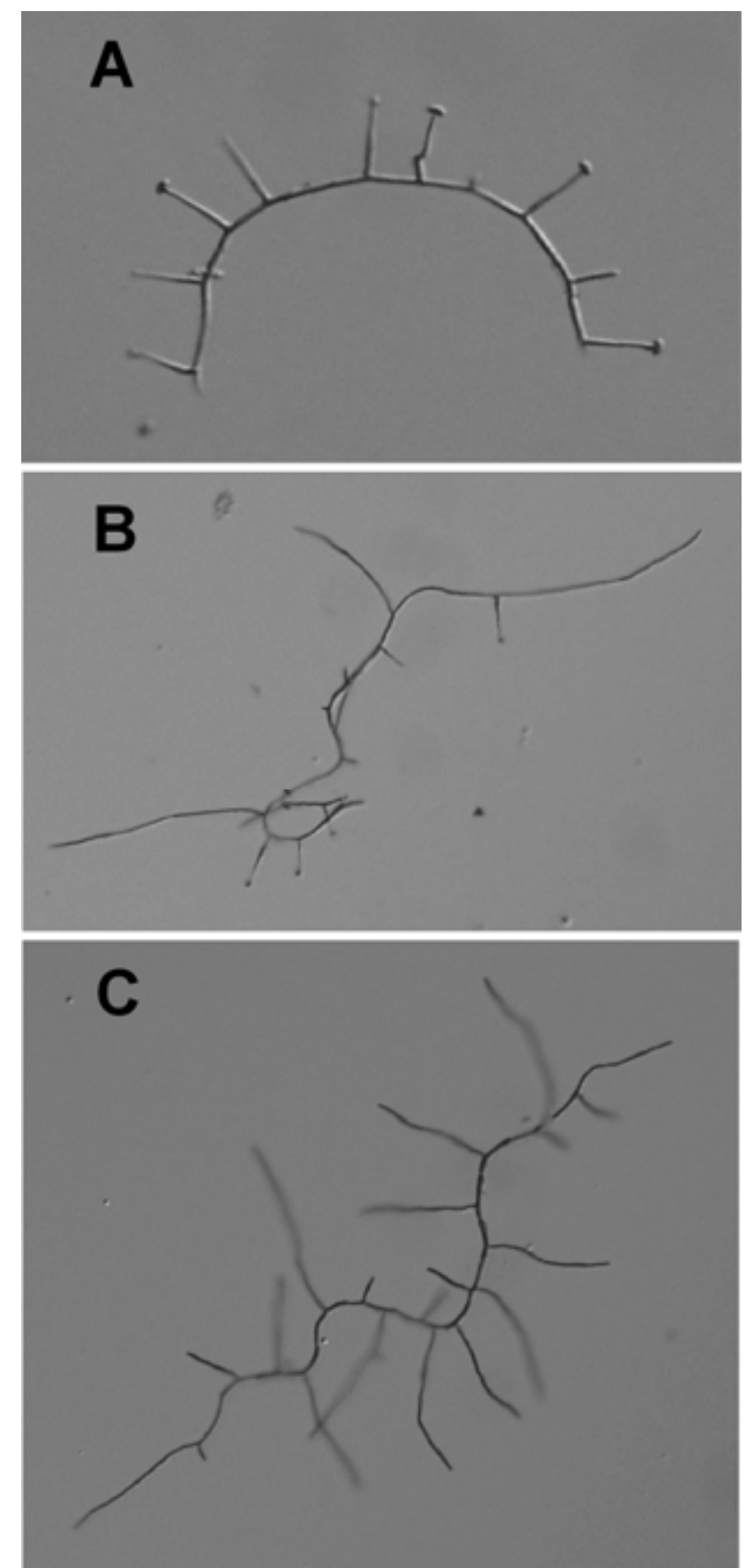

Fig. 5. A, Conidial; B, conidial and hyphal; and C, hyphal germination of ascospores of Epichloë typhina on glass slides. 
Over the winter, vegetative tillers undergo conversion (vernalization) to reproductive tillers. In the spring, if the spikelet primordium is not colonized by E. typhina, the reproductive tiller will escape infection and a healthy seed head will develop (14).

Table 1. Production of conidiophores from Epichloë typhina at injured (compression wounds from a hemostat) and uninjured sites on orchardgrass leaves in each of three experimental runs, $48 \mathrm{~h}$ after inoculation

\begin{tabular}{lccc}
\hline & \multicolumn{2}{c}{ Conidiophores per ascospore $^{\mathbf{a}}$} & \\
\cline { 2 - 3 } Run & Noninjured & Injured & $\boldsymbol{P}^{\mathbf{b}}$ \\
\hline 1 & $7.2 \pm 0.4$ & $1.9 \pm 0.3$ & $<0.001$ \\
2 & $8.0 \pm 0.2$ & $3.9 \pm 0.2$ & $<0.001$ \\
3 & $6.2 \pm 0.3$ & $3.0 \pm 0.3$ & $<0.001$ \\
\hline
\end{tabular}

${ }^{\text {a }}$ Mean \pm standard error number of conidiophores per E. typhina ascospore was based on 38 to 50 non-overlapping ascospores among three leaves.

${ }^{\mathrm{b}}$ Probability $(P)$ was calculated using the Mann-Whitney rank sum test.
Orchardgrass plants with both choked and healthy seed heads were observed by Sampson (24) and Western and Cavett (30), and are not uncommon in orchardgrass seed production fields in Oregon.

Few ascospores germinated at 5 or $10^{\circ} \mathrm{C}$. This is similar to a report of no germination of E. typhina at $10^{\circ} \mathrm{C}$ (4). Germination of ascospores of E. typhina from orchardgrass to produce a mycelium differs from the obligate iterative germination reported for ascospores of E. typhina from Sphenopholis obtusata (4). Microcyclic conidiation, as reported by Bacon and Hinton (5) for E. typhina from $S$. obtusata, was observed in E. typhina from orchardgrass but was not quantified. Bacon and Hinton (5) observed that tertiary conidia were capable of producing a mycelium. It is not clear whether E. typhina from orchardgrass produces tertiary conidia and, if so, whether they are capable of infecting leaves. Tertiary conidia were not observed in this study.

The ability of E. typhina to survive dry conditions implies that airborne ascospores could travel considerable distance with little
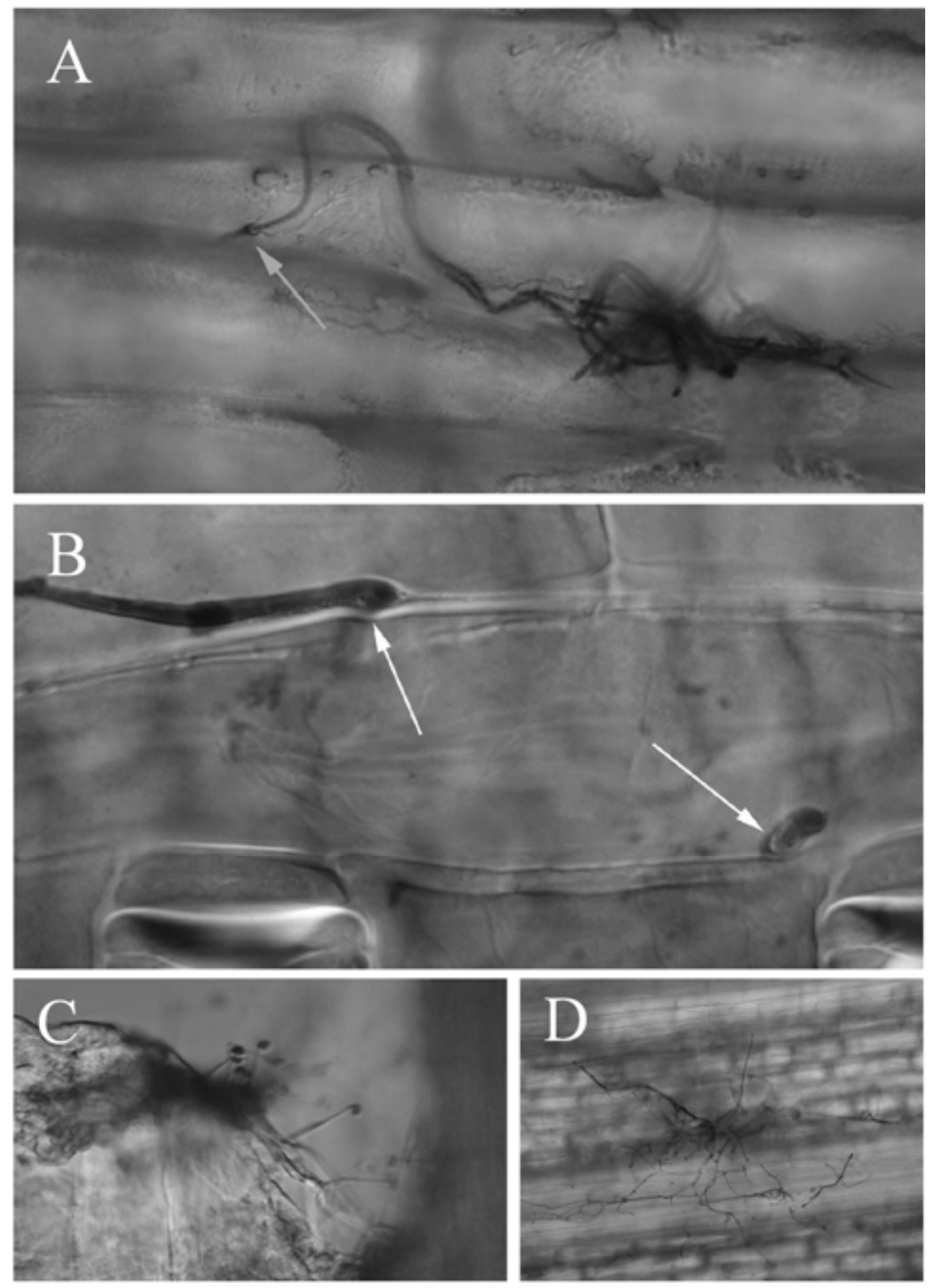

Fig. 6. Infection and epiphyllous growth of Epichloë typhina on orchardgrass leaves. A, Direct penetration of orchardgrass leaf by E. typhina (400X); B, emergence of $E$. typhina from naturally infected orchardgrass leaf $(\times 400) ; C$, conidia of $E$. typhina 10 days after inoculation of cut end of leaf $(\times 400 X)$; and $\mathbf{D}$, mycelium of $E$. typhina at a feeding site of an eriophyid mite on orchardgrass $(\times 100)$. 
Table 2. Longest germ tube length of germinating ascospores of Epichloë typhina on orchardgrass leaf surfaces after $24 \mathrm{~h}$ in the presence or absence of aphid honeydew

\begin{tabular}{lccc}
\hline & \multicolumn{2}{c}{ Germ tube length $(\boldsymbol{\mu m})^{\mathbf{a}}$} & \\
\cline { 2 - 3 } Run & Honeydew & Control & $\boldsymbol{P}^{\mathbf{b}}$ \\
\hline 1 & $49.3 \pm 3.6$ & $27.1 \pm 3.8$ & $<0.003$ \\
2 & $69.2 \pm 4.8$ & $38.4 \pm 6.2$ & $<0.008$ \\
\hline
\end{tabular}

a Mean \pm standard error germ tube length based on the mean value of the longest germ tube length for each of the first 20 ascospores encountered for each of five replicate inoculation sites.

${ }^{b}$ Probably $(P)$ calculated using a $t$ test.

reduction in viability from desiccation. This helps to account for the rapid development of E. typhina throughout the Willamette valley during the late 1990s (18). There is no evidence that conidia are windborne, and near-complete fertilization of stromata has been observed in fields with few or no flies (22). In addition to survival during dispersal, ascospores deposited on leaves could potentially survive many days of dry weather until high-moisture conditions favorable for germination occurred. The response of $E$. typhina to water potential is similar to a previous report (13). The critical points of water potential for orchardgrass plants under water stress were reported as low as -3.0 to -3.6 , depending on cultivar (29), suggesting that growth of E. typhina would not be limited in leaves of water-stressed plants.

In spring-planted orchardgrass, seed is not produced until the following spring, because vernalization is required to induce reproductive tillers. However, spring-planted fields are mowed, typically for weed management, during the time of ascospore release. It is unclear whether mowing would stimulate growth and development of E. typhina at wound sites, ultimately leading to infection.

Aphids can be problematic in orchardgrass seed production fields. There may be potential to reduce choke incidence through insect control, especially during and after the period of ascospore occurrence. However, recent field trials in which fungicides and insecticides for Botanophila spp. were evaluated for choke control do not look promising (3). However, control of aphids for reducing choke incidence has not been investigated. Currently, there are no controls for choke $(3,20,23)$ other than shorter rotations, which are costly and significantly reduce grower profits. Additional control options may be revealed through a better understanding of the timing and means by which E. typhina establishes systemic infections in orchardgrass. This study suggests that insects may be an important component of the infection process, and additional studies will be needed to further investigate this scenario.

\section{Acknowledgments}

I thank S. Rao for identification of eriophyid mites and Glenn Fisher for identification of the bird cherry-oat aphid.

\section{Literature Cited}

1. Alderman, S. C., Pfender, W. F., Welty, R. E., Mellbye, M. E., Cook, R. L., Spatafora, J. W., and Putnam, M. 1997. First report of choke, caused by Epichloë typhina, on orchard grass in Oregon. Plant Dis. 81:1335.

2. Alderman, S. C., and Rao, S. 2008. Ascosporic fertilization of Epichlö̈ typhina in Dactylis glomerata seed production fields in Oregon and implications for choke management. Plant Health Progress. Online publication. doi:10.1094/PHP-2008-0421.01-BR

3. Alderman, S. C., Rao, S., Spinney, R. L., Boren, P. K., and Cacka, J. F. 2009. Summary of choke control studies-2008. Pages 19-25 in: Seed Production Research at Oregon State University, USDA-ARS Cooperating. W. C. Young III, ed. Dep. Crop Soil Sci. Ext/Crs 128, 3/09.

4. Bacon, C. W., and Hinton, D. M. 1988. Ascosporic iterative germination in Epichlö̈ typhina. Br. Mycol. Soc. 90:563-569.
5. Bacon, C. W., and Hinton, D. M. 1991. Microcyclic conidiation cycles in Epichloë typhina. Mycologia 83:743-751.

6. Bultman, T. L., and White, J. F. 1988. "Pollination" of a fungus by a fly. Oecologia 75:317-319.

7. Bultman, B. L., White, J. F., Bowdish, T. I., Welch, A. M., and Johnston, J. 1998. Mutualistic transfer of Epichloë spermatia by Phorbia flies. Mycologia 87:182-189.

8. Chung, K. R., and Schardl, C. L. 1997. Sexual cycle and horizontal transmission of the grass symbiont, Epichloë typhina. Mycol. Res. 101:295-301.

9. Emecz, T. I., and Jones, D. G. 1970. Effect of gibberellic acid on inflorescence production in cocksfoot plants infected with choke (Epichlö̈ typhina). Trans. Br. Mycol. Soc. 55:77-82.

10. Farr, D. F., and Rossman, A. Y. Fungal Databases, Systematic Mycology and Microbiology Laboratory, ARS, USDA. http://nt.ars-grin.gov/fungal databases/

11. Heide, O. M. 1994. Control of flowering and reproduction in temperate grasses. New Phytol. 128:347-362.

12. Ju, H.-J., Hill, N. S., Abbott, T., and Ingram, K. T. 2006. Temperature influences endophyte growth in tall fescue. Crop Sci. 46:404-412.

13. Kaiser, W. J., and Bruehl, G. W. 1996. The effect of water potential upon radial growth of Epichloë and Claviceps purpurea isolates in culture. Mycologia 88:816-818

14. Kirby, J. M. 1961. Host-parasite relations in the choke disease of grasses. Trans. Br. Mycol. Soc. 44:493-503.

15. Large, E.C. 1952. Surveys for choke (Epichloë typhina) in cocksfoot seed crops, 1951. Plant Pathol. 1:23-28.

16. Large, E. C. 1954. Surveys for choke (Epichloë typhina) in cocksfoot seed crops, 1951-53. Plant Pathol. 3:6-11.

17. Leyronas, C., and Raynal, G. 2008. Roles of fungal ascospores in infection of orchardgrass (Dactylis glomerata) by Epichloë typhina agent of choke disease. J. Plant Pathol. 90:15-21.

18. Moy, M., Belanger, F., Duncan, R., Freehoff, A., Leary, C., Meyer, W., Sullivan, R., and White, J. F., Jr. 2000. Identification of Epiphyllous mycelial nets on leaves of grasses infected by Clavicipitaceous endophytes. Symbiosis 28:291-302.

19. Pfender, W. F., and Alderman, S. C. 1999. Geographical distribution and incidence of orchardgrass choke, caused by Epichloë typhina, in Oregon. Plant Dis. 83:754-758.

20. Pfender, W. F., and Alderman, S. C. 2003. Evaluation of postharvest burning and fungicides to reduce the polyetic rate of increase of choke disease in orchardgrass seed production. Plant Dis. 87:375-379.

21. Rao, S., Alderman, S. C., Kaser, J., and Hoffman, G. 2010. Bugs, slugs and exotic Epichloë typhina: close encounters of the Oregon kind. In: Proc. 7th Int. Symp. Fungal Endophytes of Grasses (ISFEG), Lexington, KY. Inoculum Newsl. Mycol. Soc. Am. (Suppl.) 61:82.

22. Rao, S., and Bauman, D. 2004. The interaction of a Botanophila fly species with an exotic Epichlö fungus in a cultivated grass: fungivore or mutualist. Entomol. Exp. Appl. 112:99-105.

23. Raynal, G. 1991. Liberation des ascospores d'Epichloë typhina, agent de la quenouille do dactyle. Consequences pour l'epidemiologie et la lutte. Fourrages 127:345-358.

24. Sampson, K. 1933. The systemic infection of grasses by Epichloë typhina (Pers.) Tul. Trans. Br. Mycol. Soc. 18:30-47.

25. Schardl, C. L., Leuchtmann, A., and Spiering, M. J. 2004. Symbioses of grasses with seedborne fungal endophytes. Annu. Rev. Plant Biol. 55:315340.

26. Schardl, C. L., and Phillips, T. D. 1997. Protective grass endophytes, where are they from and where are they going? Plant Dis. 81:430-438

27. Tadych, M., Bergen, M., Dugan, F. M., and White, J. F., Jr. 2007. The potential role of water in spread of conidia of the Neotyphodium endophyte of Poa ampla. Mycol. Res. 111:466-472.

28. Tadych, M., and White, J. F., Jr. 2007. Ecology of epiphyllous stages of endophytes and implications for horizontal transmission. In: Proc. 6th Int Symp. Fungal Endophytes of Grasses. A. J. Popay and E. R. Thom, eds N.Z. Grass Assoc. Grassland Res. Practice Ser. 13:157-161.

29. Volaire, F., and Lelievre, F. 2001. Drought survival in Dactylis glomerata and Festuca arundinacea under similar rooting conditions in tubes. Plant Soil 229:225-234.

30. Western, J. H., and Cavett, J. J. 1959. The choke disease of cocksfoot (Dactylis glomerata) caused by Epichloë typhina (Fr.) Tul. Trans. Br. Mycol. Soc. 42:298-307.

31. White, J. F., Jr., and Bultman, T. L. 1987. Endophyte-host associations in forage grasses. VIII. Heterothallism in Epichlö̈ typhina. Am. J. Bot. $74: 1716-1721$. 